\title{
Çankırı ili tarım işletmelerinin tarımsal yapı, üretim ve mekanizasyon özelliklerinin belirlenmesi
}

\section{Determination of the agriculture structure, production and mechanization properties for Çankırı province}

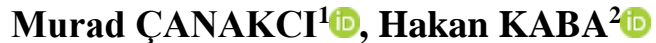 \\ ${ }^{1}$ Akdeniz Üniversitesi Ziraat Fakültesi Tarım Makinaları ve Teknolojileri Mühendisliği Bölümü, Antalya \\ ${ }^{2}$ Tarım ve Orman Bakanlığı, Denizli İl Müdürlüğü, Çameli İlçe Müdürlüğü, Çameli, Denizli \\ Sorumlu yazar (Corresponding author): M. Çanakcı, e-posta (e-mail): mcanakci@akdeniz.edu.tr \\ Yazar(lar) e-posta (Author e-mail): hakankaba@yandex.com
}

\section{MAKALE BİLGİSİ}

Alınış tarihi 10 Nisan 2019

Düzeltilme tarihi 13 Mayıs 2019

Kabul tarihi 16 Mayıs 2019

\section{Anahtar Kelimeler:}

Tarımsal üretim

Mekanizasyon araçları

Mekanizasyon düzeyi

Çankırı ili

\begin{abstract}
$\ddot{0 Z Z}$
Bu araștırmada, Cankırı ili tarımsal yapı, üretim ve mekanizasyon özelliklerinin belirlenmesi amaçlanmıştır. Çalışma kapsamında Merkez dahil 8 ilçeye ait toplam 18 köyde anket çalışması yürütülmüşsür. Anket çalışmasında 149 işletme sahibi ile yüz yüze görüşülmüştür. Araștırma bulgularına göre, tarım alanlarının yaklaşık \%96'sında kuru tarım yapılmaktadır. Başlıca ürünler buğday ve arpadır. İl genelinde tarımsal üretim belirli ürünlerde yoğunlaşırken, Kızılırmak ve Eldivan İlçelerinde ise ürün çeșitliliği gözlenmiștir. İșletmelerin yaklaşık \%70'i bitkisel ve hayvansal üretimi birlikte gerçekleştirmektedir. Çankırı il geneli için mekanizasyon düzeyi göstergeleri sırasıyla; birim alan başına düşen ortalama traktör motor gücü $2.15 \mathrm{~kW} \mathrm{ha}^{-1}$, ișletme başına düșen motor gücü $50.89 \mathrm{~kW}$ ișletme ${ }^{-1}$, traktör bașına

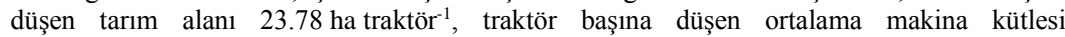
4.06 ton-makina traktör ${ }^{-1}$ ve işletme başına düşen traktör sayısı yaklaşık 1 adet işletme ${ }^{-1}$ olarak belirlenmiştir. Ayrıca işletmelerde yaklaşık bir adet elektrik motorundan hareketli makina bulunduğu tespit edilmiştir. Bu makinaların güç büyüklükleri de dikkate alındığında işletme başına düşen güç değeri $55.21 \mathrm{~kW}$ işletme ${ }^{-1}$ değerine çıkmaktadır.
\end{abstract}

\section{ARTICLE INFO}

Received 10 April 2019

Received in revised form 13 May 2019

Accepted 16 May 2019

\section{Keywords:}

Agricultural production

Mechanization vehicles

Mechanization level

Çankırı province

\begin{abstract}
In this research, it was aimed to determine agricultural structure, production and mechanization properties for Çankırı province. In the scope of the research, a questionnaire study was conducted in 18 villages belonging to 8 districts including the Center. The questionnaire was carried out face to face with the total of 149 farmers. According to the findings of the study, the ratio of rainfed farming was approximately $96 \%$, and the main products in that areas were wheat and barley. While agricultural production is concentrated in certain crops throughout the province, crop diversity has been observed in Kizilirmak and Eldivan districts. Farmers have been realizing plant production together the animal production in the ratio of $70 \%$ approximately. As the mechanization level indicators in Çankırı province, it was found that average tractor engine power per unit area is $2.15 \mathrm{~kW} \mathrm{ha}^{-1}$, tractor power per farm is $50.89 \mathrm{~kW} \mathrm{farm}^{-1}$, agricultural area per tractor is 23.78 ha tractor $^{-1}$, the average machine mass per tractor is 4.06 ton-machine tractor ${ }^{-1}$ and the number of tractors per farm is approximately 1 tractor farm ${ }^{-1}$, respectively. In addition, it was determined that the farms have approximately one machine driven by electric motor. When the power size of the machines was considered, the total power value per farm increased to $55.21 \mathrm{~kW}^{\text {farm }}{ }^{-1}$ value.
\end{abstract}

\section{Giriş}

Mekanizasyon, tarımsal üretimde kullanılan temel teknolojilerden birisidir ve mekanizasyon uygulamaları ile girdilerin daha etkin kullanımı ve çalışma koşullarının iyileşmesine katkı sağlanmaktadır. Bu nedenle işletmelerde, teknik ve ekonomik özeliklere bağlı olarak farklı düzeylerde mekanizasyon işlemleri uygulanmaktadır (Zeren ve ark. 1995). 
Tarımsal üretimin modernleşmesi ve artan toplam üretim girdileri karşısında teknolojik araçların kullanımı ve işlemlerin zamanında tamamlanması konuları öne çıkmaktadır. $\mathrm{Bu}$ nedenle, tarımsal mekanizasyon araçlarının seçimi, optimum büyüklüklerde kullanımı, işletilmesi bakımı vb. konular önem kazanmaktadır. Mekanizasyon araçlarını etkin, doğru, verimli ve sürdürülebilir bir şekilde kullanmak esastır. Bu kapsamda yapılacak çalışmalarda mekanizasyon yatırımlarının, bölgeye yönelik planlı ve uygun bir şekilde yapılabilmesi için, bölgeye ait tarımsal yap1 ve mekanizasyon özelliklerinin bilinmesi gerekmektedir (Akınc1 ve ark. 1997).

Ülkemizde ve dünyada anket çalışması ya da istatistiki veriler kullanılarak, tarımsal mekanizasyon ile ilgili veri tabanlarının oluşturulmasına yönelik il, bölge ve ülke düzeyinde birçok çalışma yürütülmektedir (Singh 1999; Sağlam ve Akdemir 2002; Altuntaş ve Demirtola 2004; Çiçek ve Özpınar 2007; Evcim ve ark. 2010; Altıkat ve Çelik 2011; Lüle ve ark. 2012; Gökdoğan 2013; Magalhães ve ark. 2013; Baran ve ark. 2014; Ademoğlu 2015; Keleş 2015; Comart 2016). Bu çalışmalarda; tarımsal üretim potansiyeli ile birlikte tarımsal mekanizasyon araçlarının varlığı belirlenmekte, mekanizasyon düzeyleri ve sorunlar tespit edilmekte, çözüm önerileri sunulmaktadır. Araştırmalarda elde edilen bulgular; özellikle politika belirleme, planlama, bölgelerarası kıyaslama vb. çalışmalar için kullanılabilir özellikteki verileri içermektedir.

Çankırı ili İç Anadolu bölgesinde yer almaktadır ve il ekonomisi ve istihdamında tarım ve hayvancılığın önemi büyüktür. Yapılan çalışmalar incelendiğinde Çankırı ilinin tarımsal mekanizasyon özelliklerinin belirlenmesine yönelik bir çalışmaya rastlanılmamıştır. Bu çalışmada, Çankırı ilinde tarımsal yapı ve üretim özellikleri ile birlikte mekanizasyon özelliklerinin belirlenmesi amaçlanmıştır.

\section{Materyal ve Metot}

Çalışmanın ana materyalini Çankırı ilinde tarımsal üretim yapan geleneksel işletmeler oluşturmaktadır. İlin yüzölçümü 749000 ha'dır ve 11 ilçe, üç belde ve 375 köyden oluşmaktadır. Toplam yüzölçümünün \%36'sını tarım alanları, \%26'sını çayır-mera alanları, \%20'sini ise ormanlık alanlar oluşturmaktadır (Anonim 2017). İlde yazların sıcak ve kurak, kışların soğuk ve sert geçtiği tipik karasal iklim görülmektedir (Cengil 2013). Uzun yıllar ortalamasına (1950-2015) göre yıllık ortalama sıcaklık değeri $11.3^{\circ} \mathrm{C}$, y1llık ortalama toplam yağış miktarı ise 410.6 mm'dir (MGM 2016).

Araştırmada veriler yüz yüze yapılan anket çalışması ile elde edilmiştir. Anket çalışması için, il genelini temsil edecek şekilde gayeli olarak 8 ilçe ve bu ilçelere bağlı 18 köy seçilmiştir. Köylerden toplanan kayıtlı veriler dikkate alınarak anket yapılacak işletme sayısı belirlenmiştir. Bu amaçla Tarım ve Orman Bakanlığı Çiftçi Kayıt Sistemi (ÇKS) veri tabanından yararlanılmıştır (ÇKS 2017). Anket yapılacak işletme sayısının belirlenmesinde tabakalı örnekleme yöntemi kullanılmış ve Neyman eşitliklerinden yararlanılmıştır. Hesaplanan örnek hacim değerleri çalışma güvenirliliği açısından \%30 artırılmıştır (Özkan 1993; Çanakcı 2005). Anket çalışması 2018 y11 içerisinde; Çerkeş, Kurşunlu, Ilgaz, Şabanözü, Eldivan, Kızılırmak, Yapraklı ve Merkez ilçelerinde toplam 149 adet işletmede yürütülmüştür.

Anket çalışmasında işletme genel özellikleri, bitkisel ve hayvansal üretim özellikleri, işletmede kullanılan güç kaynakları ve mekanizasyon araçları ile ilgili sorular sorulmuştur. Elde edilen veriler MS-Excel tablolama programında değerlendirilerek tarımsal yap1, üretim ve mekanizasyon varlıklarına ait veriler belirlenmiştir.

\section{Bulgular ve Tartışma}

\section{1. İşletmelerin genel özellikleri}

Anket yapılan işletme sahiplerinin deneyim süreleri 2 ile 60 y1l arasında değişmektedir ve ortalama 28.6 yıl olarak belirlenmiştir. Ailedeki ortalama kişi sayısı 4.1'dir. Anket verilerine göre 149 işletme sahibi arasında beş kişi (\%3.4) 10 yılın altında deneyime sahiptir. Tarımsal üretimin çoğunlukla orta yaş ve üzeri kişiler tarafindan yapıldığı söylenebilir. İşletme sahiplerinin yaklaşık \%75'i ilköğretim, \%19'u lise ve \%6's1 ise üniversite mezundur. İlçeler değerlendirildiğinde Kızılırmak ilçesindeki ilkokul mezunu oranının diğer ilçelere göre daha yüksek olduğu görülmektedir. Üniversite mezunlarının tümünün coğrafi olarak aynı hat üzerinde bulunan Çerkeş, Kurşunlu ve Ilgaz ilçelerinde tespit edilmesi dikkat çekicidir.

\subsection{Tarımsal yapı ve üretim özellikleri}

Anket yapılan işletmelerin toplam tarımsal alanları, parsel sayıları ve bu değerlere bağlı olarak hesaplanan ortalama parsel büyüklüğü değerleri Çizelge 1'de verilmiştir.

İncelenen 149 adet işletmenin toplam arazi büyüklüğü 3565 ha, ortalama işletme büyüklüğü ise 22.9 ha'dır. İşletmelerde toplam 4327 adet parsel belirlenmiştir ve işletme başına düşen parsel sayısı ortalama 28.2 adettir. Bu durumda ortalama parsel büyüklüğü 0.81 ha olarak hesaplanmaktadır. Parsel sayısının fazla, ölçeklerinin ise küçük olduğu görülmektedir. İşletme başına düşen en fazla tarım alanı 37 ha işletme ${ }^{-1}$ ile Kurşunlu ilçesinde, en düşük tarım alanı ise 11.4 ha işletme ${ }^{-1}$ değeri ile Eldivan ilçesinde belirlenmiştir.

Çizelge 1. İşletme ve parsel büyüklükleri.

Table 1. Farm and parcel sizes.

\begin{tabular}{lcccccc}
\hline İlçe & $\begin{array}{c}\text { İşletme Sayısı } \\
\text { (adet) }\end{array}$ & $\begin{array}{c}\text { Toplam Üretim } \\
\text { Alanı (ha) }\end{array}$ & $\begin{array}{c}\text { Parsel SayıSI } \\
\text { (adet) }\end{array}$ & $\begin{array}{c}\text { Isşletme Başına } \\
\text { Düşen Alan (ha) }\end{array}$ & $\begin{array}{c}\text { İşletme Başına Düşsen } \\
\text { Parsel Sayısı (adet) }\end{array}$ & $\begin{array}{c}\text { Ortalama Parsel } \\
\text { Büyüklüğü (ha) }\end{array}$ \\
\hline Çerkeş & 19 & 673.4 & 838 & 35.4 & 44.1 & 0.80 \\
Kurşunlu & 21 & 775.3 & 787 & 36.9 & 37.5 & 0.99 \\
Ilgaz & 12 & 291.5 & 297 & 24.3 & 24.8 & 0.98 \\
Şabanözü & 16 & 213.6 & 249 & 13.4 & 15.6 & 0.86 \\
Eldivan & 15 & 170.9 & 330 & 11.4 & 22.0 & 0.52 \\
Kızılırmak & 27 & 658.0 & 620 & 24.4 & 23.0 & 1.06 \\
Yapraklı & 14 & 191.1 & 339 & 13.7 & 24.2 & 0.56 \\
Merkez & 25 & 591.2 & 867 & 23.6 & 34.7 & 0.68 \\
Toplam & $\mathbf{1 4 9}$ & $\mathbf{3 5 6 5 . 0}$ & $\mathbf{4 3 2 7}$ & $\mathbf{2 2 . 9}$ & $\mathbf{2 8 . 2}$ & $\mathbf{0 . 8 1}$ \\
\hline
\end{tabular}


Tarım alanlarının \%96.1'i kuru tarım \%23.9'u ise nadas alanıdır. Kızılırmak ve Eldivan ilçelerinde sulu tarım alanlarının toplam tarım alanlarına oranı sırasıyla \%15.6 ve \%9.4'tür. Diğer ilçelerde ise bu oran \%1-2 gibi düşük düzeylerdedir.

İşletme sahiplerinin $\% 27.5$ 'i kendi mülkünde tarımsal üretim yapmaktadır. Öz mülkü ile birlikte kiralık arazi kullanan işletme oranı \%69.1'dir. Yalnızca kiralık arazide üretim yapılan işletme oranı ise \%3.4 düzeyindedir. Genel yapısı dikkate alındığında dışarı göç vermiş bir bölge olan Çankırı ilinde, genellikle il dışında yaşayan kişilerin arazileri kiralanmaktadır. $\mathrm{Bu}$ alanların kiralanmadığı durumda büyük oranda boş kalacak olması nedeniyle düşük fiyatlarla ya da küçük ayni destekler şeklinde kiralanması söz konusudur. Mevcut durumun ölçeklerinin artmasına imkân vermesi nedeniyle, bölge işletmeleri için bir firsat olduğu söylenebilir.

\subsubsection{Bitkisel üretim kollart ve ürün deseni}

Tarımsal işletmelerde yetiştirilen ürünlerin dağılımı Çizelge 2'de verilmiştir.

Toplam tarım alanlarından nadas alanları çıkartıldığında, 2741 ha olarak yetiştiricilik yapılan alan kalmaktadır. Tarla bitkileri alanları ise toplam ekilen alanların yaklaşık \%99'unu oluşturmaktadır. Başlıca yetiştirilen ürünler sırasıyla buğday (\%58.6) ve arpadır (\%19.8). Tarla bitkilerinde yonca, korunga, fiğ, tritikale gibi ürünlerin toplam alanlar içerisindeki payı yaklaşık \%15'tir. Yalnızca Kızılırmak ilçesinde yetiştirilen çeltik bitkisinin payı \%3.4 düzeyindedir. Sulu tarımın yapıldığ Kızılırmak ve Eldivan ilçeleri gibi lokal bölgelerde yetiştirilen meyve ve sebze alanlarının toplam alanlar içerisindeki payları yaklaşık \%1 gibi oldukça düşük düzeylerdedir.

İşletmelerin yaklaşı \%50'si tarla bitkileri ve hayvan yetiştiriciliğini birlikte yürütmektedir. Yalnızca tarla bitkileri yetiştiriciliği yapılan işletme sayısı toplam işletmelerin $\% 24.8$ 'ini oluşturmaktadır. Sebze ve meyve yetiştiriciliğinin diğer üretim kolları ile birlikte yapıldığı işletmeler daha düşük oranlarda belirlenmiştir.

Çizelge 2. İşletmelerde yetiştirilen ürünler ve alanları.

Table 2. Cultivated crops in the farms, and their areas.

\begin{tabular}{|c|c|c|c|}
\hline \multirow{2}{*}{ Üretim Dalı } & \multirow{2}{*}{ Ürün Cinsi } & \multirow{2}{*}{$\begin{array}{c}\text { Üretim Alanı } \\
\text { (ha) }\end{array}$} & \multirow{2}{*}{$\begin{array}{c}\text { Toplam } \\
(\%)\end{array}$} \\
\hline & & & \\
\hline \multirow{12}{*}{ Tarla Bitkileri } & Buğday & 1606.4 & 58.6 \\
\hline & Arpa & 543.0 & 19.8 \\
\hline & Tritikale & 64.8 & 2.4 \\
\hline & Fiğ & 95.6 & 3.5 \\
\hline & Korunga & 229.6 & 8.4 \\
\hline & Yonca & 20.0 & 0.7 \\
\hline & Çeltik & 92.0 & 3.4 \\
\hline & Nohut & 2.0 & 0.1 \\
\hline & Yulaf & 38.7 & 1.4 \\
\hline & Aspir & 5.5 & 0.2 \\
\hline & Şeker Pancarı & 12.5 & 0.5 \\
\hline & Toplam & 2710.1 & 98.9 \\
\hline \multirow{3}{*}{ Sebze (Açık) } & Kavun & 20.3 & 0.7 \\
\hline & Açıkta Sebze & 1.9 & 0.1 \\
\hline & Toplam & 22.2 & 0.8 \\
\hline \multirow{5}{*}{ Meyve } & Kiraz+Vişne & 2.2 & 0.1 \\
\hline & Ceviz & 1.7 & 0.1 \\
\hline & Elma & 3.3 & 0.1 \\
\hline & Armut & 1.5 & 0.1 \\
\hline & Toplam & 9.0 & 0.3 \\
\hline Genel Toplam & & 2741 & 100.0 \\
\hline
\end{tabular}

\subsubsection{Hayvan varliğ}

Çankırı ilinde hayvansal üretim önemli bir yere sahiptir. Büyükbaş hayvan yetiştiriciliği tüm ilçelerde yapılmaktadır. Çizelge 3'de işletmelerde belirlenen hayvan sayılarına ilişkin değerler verilmiştir.

Toplam 149 işletmenin 101 'in de (\%67.8) sığır yetiştiriciliği yapılmaktadır ve bu işletmelerdeki sığır sayısı 3154 adettir. Toplam sayının yaklaşık \%88'i (2772 adet) süt sığırıdır. En fazla hayvan sayısı sırasıyla, 50 ve 41 adet ișletme $^{-1}$ ile Kurşunlu ve Çerkeş ilçelerinde tespit edilmiştir. İl genelinde işletme başına düşen ortalama sığır sayısı 28.4'tür. Bu rakamlar ile il genelinde bitkisel üretim ile birlikte yapılan hayvansal üretimin önemli bir geçim kaynağ1 olduğu söylenebilir.

Küçükbaş hayvan yetiştiriciliği yapılan işletme sayısı, büyükbaş hayvan yetiştiriciliğine kıyasla daha azdır. Toplam 16 adet işletmede koyun, 10 adet işletmede ise keçi yetiştirildiği belirlenmiştir. İl genelinde küçükbaş hayvancılık yapılan işletmelerdeki ortalama koyun ve keçi sayıları ise sırasıyla 98.0 ve 37.1 'dir. En fazla küçükbaş hayvan yetiştiriciliğinin yapıldığ 1 ilçe, 4 adet işletmede koyun ve 3 adet işletmede keçi yetiştiriciliği ile Eldivan'dır. $\mathrm{Bu}$ ilçeye ait işletmelerdeki ortalama koyun ve keçi sayıları sırasıyla 195.0 ve 141.7 'dir.

\subsection{Tarımsal Mekanizasyon Özellikleri}

\subsubsection{Traktör varlı̆̆}

Araştırma kapsamında incelenen işletmelerdeki traktörlerin ilçelere göre dağılımı Çizelge 4'de verilmiştir.

İşletmelerde toplam 150 adet traktör bulunmaktadır. Toplam 17 adet (\%11.4) işletmede traktör bulunmaz iken, 18 adet (\%12.1) işletme ise iki adet traktöre sahiptir. İşletme başına ortalama yaklaşık bir adet traktör düşmektedir (Çizelge 4). Belirlenen traktörlerin markalara göre dağılımı Çizelge 5'de yer almaktadir.

Çizelge 5'de görüldügü gibi işletmelerde 13 markaya ait 33 farklı tip traktör belirlenmiştir. Massey Ferguson \%39.3 payla en fazla tercih edilen markadır. Bu markayı \%20.7 ile New Holland ve \%9.3 ile Tümosan markaları izlemiştir. Traktörlerin ortalama motor gücü $51.2 \mathrm{~kW}$ olarak hesaplanmıştır.

Anket çalışmasında elde edilen bulgular değerlendirildiğinde; işletmelerde en fazla traktörün \%30.0'luk pay ile $40.1-50 \mathrm{~kW}$ güç grubunda yer aldığı, bu güç grubunu sirasiyla \%24.7 ve \%20.0'lik paylar ile $50.1-60 \mathrm{~kW}$ ve $60.1 \geq \mathrm{kW}$ güç gruplarının izlediği belirlenmiştir. $\mathrm{Bu}$ dağılım tüm ilçelerde aynı olmamakla birlikte, üretim alanları fazla olan Çerkeş ve Kurşunlu gibi ilçelerde daha güçlü traktörlerin çoğunlukta olduğu saptanmıştır. Traktörlerin yaş grupları dikkate alındığında, en çok traktör \%50.7'lik oran ile 0-5 yaş grubundadır. $\mathrm{Bu}$ yaş grubunu \%19.3'lük pay ile en yaşlı traktörlerin yer aldığ $131 \geq$ yaş grubu izlemektedir. Diğer gruplar olan $6-10, \quad 11-15, \quad 16-20$ ve $21-30$ yaş sinır değerlerindeki traktörlerin oranları sırasıyla; \%5.3, \%8.0, \%5.3 ve \%11.3'tür. İlçeler dikkate alındığında aynı havzada yer alan Çerkeş, Kurşunlu ve Ilgaz ile sulu tarımında yapıldığ Kızılırmak ilçelerinde daha çok yeni traktörlerin kullanıldığ tespit edilmiştir. Yılmaz ve Sümer (2018) tarafindan yapılan bir çalışmada, traktörlerin ekonomik ömürlerinin 20 y1l olarak kabul edilmesinin ülkemiz koşullarında daha gerçekçi olduğu belirtilmiştir. Bu değer dikkate alındığında anket çalışmasında belirlenen traktörlerin \%69.3'ünün ekonomik ömür içerisinde olduğu söylenebilir. 


\subsubsection{Tarım makinaları varlığl}

Çizelge 6'da traktör ve işletme başına düşen makina kütlesi ve makina sayısı verilmiştir.

Çizelge 6'da görüldüğü gibi işletmelerde traktör ile çalıştırılan toplam 928 adet tarım makinası bulunmaktadır. Makinaların toplam kütlesi yaklaşık 611 ton'dur. Traktör başına düşen makina kütlesi yaklaşık 4.07 ton ve tarım makinası sayısı ise 6.25 adet olarak belirlenmiştir. Traktör başına en fazla yaklaşık 0.9 adet traktör ${ }^{-1}$ değeri ile kulaklı pulluk, kültüvatör ve tarım arabası düşmektedir. Bu makinaları 0.70 adet traktör $^{-1}$ ile tahıl ekim makinası izlemektedir. Hayvancılık işletmelerinde kullanılan yem karma makinası sayısı ise 20'dir. Bu değer ile toplam sayıs1 101 adet olan hayvancılığın yapıldı $\breve{g} 1$ işletmelerde yem karma makinası kullanım oranı yaklaşı \%20 olarak hesaplanmaktadır.

Traktör ile çalışan 928 tarım makinasının yaklaşık \%40'ının $\leq 5$ yaş grubunda yer aldığı görülmektedir. Yirmi yaşın üzerindeki makinaların oranı ise \%16.6'dır.

Çalışmada ayrıca elektrik motorundan hareketli makinalar da değerlendirilmiştir. Çizelge 7'de elektrik motorundan hareketli makinaların ilçelere göre dağılımı verilmiştir.

İşletmelerde toplam 151 adet elektrik motorundan hareketli makina bulunmaktadır. Bu makinalar; süt sağım makinaları, yem kırma makinaları, helezon ve su pompalarıdır. Hayvancılık işletmelerinde insan işgücü ile yapılan bazı işlemlerin geleneksel işletmelerde makinalar ile yapılmaya başlaması önemlidir. Makinalar içerisinde toplam 79 makina (\%52.3) ile en fazla süt sağım makinası bulunmaktadır (Çizelge 7). Tarımsal mekanizasyonda yaygın olarak kullanılan güç kaynağının traktör olması nedeniyle mekanizasyon özelliklerinin belirlenmesine yönelik yapılan bazı çalıșmalarda elektrik motorundan hareketli makinaların göz ardı edildiği görülmektedir. Ancak teknolojik gelişmelere bağlı olarak özellikle sabit tesislerde traktör yerine elektrik motorlarının güç kaynağı olarak kullanılması yaygınlaşmaktadır. $\mathrm{Bu}$ nedenle bu çalışmada elde edilen bulguların ülkemiz veri tabanını zenginleştireceği söylenebilir.

\subsubsection{Mekanizasyon düzeyi göstergeleri}

Araştırma kapsamında incelenen işletmelerin mekanizasyon düzeyi göstergelerine ilişkin değerler Çizelge 8'de verilmiştir.

Çizelge 8'de görüldüğü gibi Çankırı İli genelinde birim alan başına düşen ortalama traktör motor gücü $2.15 \mathrm{~kW} \mathrm{ha}^{-1}$, işletme başına düşen motor gücü $50.89 \mathrm{~kW}$ işletme ${ }^{-1}$, traktör başına düşen tarım alanı 23.78 ha traktör ${ }^{-1}$, traktör başına düşen ortalama makina kütlesi 4.06 ton-makina traktör-1 ${ }^{-1}$ ve işletme başına düşen traktör sayıs1 1.01 traktör işletme ${ }^{-1}$ olarak belirlenmiştir.

Farklı ürünlerin yetiştirildiği Kızılırmak ilçesinde birim alan başına düşen güç büyüklüğü $1.79 \mathrm{~kW} \mathrm{ha}^{-1}$ ile en düşük değerdedir. Yine işletme başına düşen traktör sayısının 1'den büyük olduğu Çerkeş ve Kurşunlu gibi ilçelerde, traktör başına işlenen alan ve traktör başına düşen makina kütlesinin fazla olmasının yanında birim alana düşen güç büyüklük değerlerinin düşük kaldığı görülmektedir. Birim alan başına düșen ortalama traktör gücü $4.26 \mathrm{~kW} \mathrm{ha}^{-1}$ değeri ile parsel büyüklügünün ve işletme başına düşen tarım alanının en düşük olduğu Eldivan ilçesi için hesaplanmıştır.

Çankırı ili geneli için belirlenen mekanizasyon düzeyi göstergelerinin Balıkesir, Çanakkale, Tekirdağ, Edirne, Kırklareli illerinin yer aldığı Batı Marmara bölgesi için Baran ve ark. (2014) tarafından hesaplanmış değerlerden daha düşük olduğu görülmektedir. Batı Marmara bölgesi için $3.07 \mathrm{~kW} \mathrm{ha}^{-1}$ olarak hesaplanan birim alan başına düşen traktör

Çizelge 3. İşletmelerdeki hayvan sayılarının ilçelere göre dağılımı.

Table 3. Distribution of cow numbers in the farms.

\begin{tabular}{|c|c|c|c|c|c|c|c|c|c|}
\hline \multirow{2}{*}{ İlçeler } & \multirow{2}{*}{$\begin{array}{c}\text { İşletme Sayısı } \\
\text { adet }\end{array}$} & \multicolumn{2}{|c|}{ Sığır Sayısı } & \multirow{2}{*}{$\frac{\text { İşletme Sayısı }}{\text { adet }}$} & \multicolumn{2}{|c|}{ Koyun Sayısı } & \multirow{2}{*}{$\frac{\text { İşletme Sayısı }}{\text { adet }}$} & \multicolumn{2}{|c|}{ Keçi Sayısı } \\
\hline & & adet & adet işletme $^{-1}$ & & adet & adet işletme $^{-1}$ & & adet & adet işletme $^{-1}$ \\
\hline Çerkeş & 17 & 697 & 41.0 & - & - & - & - & - & - \\
\hline Kurşunlu & 19 & 943 & 49.6 & 2 & 220 & 2 & 2 & 55 & 27.5 \\
\hline Ilgaz & 11 & 331 & 30.1 & 1 & 30 & 1 & 1 & 10 & 10.0 \\
\hline Şabanözü & 10 & 182 & 18.2 & 4 & 23 & 4 & 3 & 13 & 4.3 \\
\hline Eldivan & 11 & 363 & 33.0 & 4 & 780 & 4 & 3 & 425 & 141.7 \\
\hline Kızılırmak & 11 & 244 & 22.2 & - & - & - & - & - & - \\
\hline Yapraklı & 8 & 97 & 12.1 & 2 & 140 & 2 & - & - & - \\
\hline Merkez & 12 & 297 & 24.8 & 3 & 532 & 3 & 1 & 2 & 2.0 \\
\hline Genel & 101 & 3154 & 28.4 & 16 & 1725 & 16 & 10 & 505 & 37.1 \\
\hline
\end{tabular}

Çizelge 4. Traktörlerin ilçelere göre dağılımı.

Table 4. Distribution of tractors according to the districts.

\begin{tabular}{|c|c|c|c|c|c|c|c|}
\hline \multirow{3}{*}{ İlçeler } & & \multicolumn{3}{|c|}{ Traktör Sayısı (adet işletme ${ }^{-1}$ ) } & \multirow{3}{*}{$\begin{array}{l}\text { İşletme Sayısı } \\
\text { (adet) }\end{array}$} & \multirow{3}{*}{$\begin{array}{c}\text { Toplam Traktör Sayısı } \\
\text { (adet) }\end{array}$} & \multirow{3}{*}{$\begin{array}{c}\text { traktör işletme }{ }^{-1} \\
\text { (adet) }\end{array}$} \\
\hline & & 0 & 1 & 2 & & & \\
\hline & & \multicolumn{3}{|c|}{ İşletme Sayısı (adet) } & & & \\
\hline Çerkeş & & 1 & 14 & 4 & 19 & 22 & 1.2 \\
\hline Kurşunlu & & 0 & 16 & 5 & 21 & 26 & 1.2 \\
\hline Ilgaz & & 1 & 8 & 3 & 12 & 14 & 1.2 \\
\hline Şabanözü & & 2 & 13 & 1 & 16 & 15 & 0.9 \\
\hline Eldivan & & 1 & 12 & 2 & 15 & 16 & 1.1 \\
\hline Kızılırmak & & 5 & 21 & 1 & 27 & 23 & 0.9 \\
\hline Yapraklı & & 5 & 9 & 0 & 14 & 9 & 0.6 \\
\hline Merkez & & 2 & 21 & 2 & 25 & 25 & 1.0 \\
\hline \multirow{2}{*}{ Toplam } & adet & 17 & 114 & 18 & 149 & 150 & 1.01 \\
\hline & $\%$ & 12 & 76 & 12 & - & - & - \\
\hline
\end{tabular}


Çizelge 5. Traktörlerin markalara göre dağılımı.

Table 5. Distribution of tractors according to the trade marks.

\begin{tabular}{|c|c|c|c|c|c|c|c|}
\hline \multirow{2}{*}{ Marka ve Tip } & \multirow{2}{*}{ Motor Gücü (kW) } & \multicolumn{2}{|c|}{ Traktör Sayısı } & \multicolumn{2}{|c|}{ Toplam Güç* } & \multicolumn{2}{|c|}{ Toplam } \\
\hline & & adet & $\%$ & $\mathbf{k W}$ & $\%$ & adet & $\%$ \\
\hline CASE JX75C & 55.9 & 9 & 6.0 & 503.1 & 6.6 & 9 & 6.0 \\
\hline ERKUNT BEREKET60 & 44.7 & 2 & 1.3 & 89.4 & 1.2 & & \\
\hline ERKUNT NİMET70 & 52.2 & 4 & 2.7 & 208.8 & 2.8 & & \\
\hline ERKUNT SERVET80 & 59.7 & 2 & 1.3 & 119.4 & 1.6 & 11 & 7.3 \\
\hline ERKUNT KUDRET100 & 74.6 & 3 & 2.0 & 223.8 & 2.9 & & \\
\hline Fendt & 93.2 & 1 & 0.7 & 93.2 & 1.2 & 1 & 0.7 \\
\hline FIAT 480 & 35.8 & 2 & 1.3 & 71.6 & 0.9 & & \\
\hline FIAT $54 \mathrm{C}$ & 40.3 & 2 & 1.3 & 80.6 & 1.0 & 10 & \\
\hline FIAT 55-56 & 41.0 & 3 & 2.0 & 123 & 1.6 & 10 & 6.7 \\
\hline FIAT $60-56$ & 44.7 & 3 & 2.0 & 134.2 & 1.7 & & \\
\hline FORD3610S & 35.8 & 2 & 1.3 & 71.6 & 0.9 & 4 & 28 \\
\hline FORD5000 & 55.9 & 2 & 1.3 & 111.8 & 1.5 & 4 & 2.8 \\
\hline JOHN DEERE5075E & 55.9 & 3 & 2.0 & 167.7 & 2.2 & & 41 \\
\hline JOHN DEERE5095 & 70.8 & 3 & 2.0 & 212.5 & 2.8 & 6 & 4.1 \\
\hline MF 135 & 34.3 & 14 & 9.3 & 480.2 & 6.3 & & \\
\hline MF $240 \mathrm{~S}$ & 35.8 & 19 & 12.7 & 680.2 & 8.9 & & \\
\hline MF165 & 48.4 & 8 & 5.3 & 387.2 & 5.2 & & \\
\hline MF 265 & 48.4 & 8 & 5.3 & 387.2 & 5.2 & 59 & 39.3 \\
\hline MF 277G & 55.9 & 3 & 2.0 & 167.1 & 2.2 & & \\
\hline MF 285 & 63.4 & 4 & 2.7 & 253.2 & 3.3 & & \\
\hline MF 5450 & 78.2 & 3 & 2.0 & 234.6 & 3.1 & & \\
\hline NH TT55 & 41.0 & 6 & 4.0 & 246 & 3.2 & & \\
\hline NH TT65 & 48.4 & 9 & 6.0 & 435.6 & 5.7 & 21 & \\
\hline NH TD75 & 55.9 & 11 & 7.3 & 614.9 & 8.0 & 31 & 20.7 \\
\hline NH TD110 & 82.0 & 5 & 3.3 & 410 & 5.3 & & \\
\hline SAME BUFFALO & 44.7 & 1 & 0.7 & 44.7 & 0.6 & 1 & 0.7 \\
\hline STEYR 545 & 35.8 & 1 & 0.7 & 35.8 & 0.5 & 1 & 0.7 \\
\hline TÜMOSAN6065 & 48.4 & 3 & 2.0 & 145.2 & 1.9 & & \\
\hline TÜMOSAN8075 & 55.9 & 2 & 1.3 & 111.8 & 1.5 & 14 & 02 \\
\hline TÜMOSAN8095 & 70.8 & 7 & 4.7 & 495.6 & 6.5 & 14 & 9.3 \\
\hline TÜMOSAN8105 & 78.2 & 2 & 1.3 & 156.4 & 2.0 & & \\
\hline UNIVERSAL U-643 & 47.7 & 1 & 0.7 & 47.7 & 0.6 & 1 & 0.7 \\
\hline VALTRA A85 & 65.6 & 2 & 1.3 & 131.2 & 1.7 & 2 & 1.3 \\
\hline Toplam & & 150 & 100 & 7676 & 100 & 150 & 100 \\
\hline
\end{tabular}

*Ortalama Traktör Gücü: 51.2 kW.

Çizelge 6. Traktör ve işletme başına düşen makina kütlesi ve makina sayısı.

Table 6. Number and masse of the machinery per a tractor and a farm.

\begin{tabular}{|c|c|c|c|c|c|c|c|c|c|}
\hline \multirow{2}{*}{ Makina } & \multirow{2}{*}{ Özellik } & \multirow{2}{*}{ Yaygın Tip } & \multicolumn{3}{|c|}{ Makina Sayısı Makina Kütlesi Toplam Kütle } & \multicolumn{2}{|c|}{ makina traktör ${ }^{-1}$} & \multicolumn{2}{|c|}{ makine işletme $^{-1}$} \\
\hline & & & adet & kg & kg & kg & adet & kg & adet \\
\hline Pulluk & Kulaklı & $3-5$ & 135 & 380 & 51300 & 342.0 & 0.90 & 344.3 & 0.91 \\
\hline Çizel & 6-7ayaklı & 7 & 7 & 270 & 1890 & 12.6 & 0.05 & 12.7 & 0.05 \\
\hline Diskaro & 28diskli & 28 & 16 & 350 & 5600 & 37.3 & 0.11 & 37.6 & 0.11 \\
\hline Kültüvatör & Yarı yaylı & $9-11$ & 132 & 250 & 33000 & 220 & 0.90 & 221.5 & 0.89 \\
\hline Tapan & Sürgü & - & 55 & 470 & 25850 & 172.3 & 0.37 & 173.5 & 0.37 \\
\hline Sant. Gübre Dağıtma Mak. & Diskli & Tek disk & 66 & 80 & 5280 & 35.2 & 0.44 & 35.4 & 0.44 \\
\hline Toprak Frezesi & Bıçak & $36-42$ & 10 & 500 & 5000 & 33.3 & 0.07 & 33.6 & 0.07 \\
\hline Tahıl Ek. Mak. & 14-18ayak & $14-16$ & 99 & 850 & 84150 & 561 & 0.70 & 564.8 & 0.66 \\
\hline Pülverizatör & 400 1- Asma & 4001 & 71 & 500 & 35500 & 236.7 & 0.47 & 238 & 0.48 \\
\hline Tarım Arabası & Tek aks & $2-3$ ton & 43 & 1150 & 49450 & 329.7 & 0.29 & 331.9 & 0.29 \\
\hline Tarım Arabası & Çift aks & 4-5 ton & 66 & 1400 & 92400 & 616 & 0.44 & 620.1 & 0.44 \\
\hline Tarım Arabası & Çift aks & 7 ton & 27 & 2300 & 62100 & 414 & 0.18 & 416.8 & 0.18 \\
\hline Ot Biçme Makinası & Tamburlu & -2 & 54 & 350 & 18900 & 126 & 0.36 & 126.8 & 0.36 \\
\hline Ön Yükleyici & Hidrolik & - & 14 & 170 & 2380 & 15.9 & 0.09 & 16 & 0.09 \\
\hline Arka Yükleyici & Hidrolik & - & 20 & 170 & 3400 & 22.7 & 0.13 & 22.8 & 0.13 \\
\hline Balya Makinası & Prizmatik & Küçük & 15 & 2050 & 30750 & 205 & 0.10 & 206.4 & 0.10 \\
\hline Ot Tirmıkları & Çekilir & Yıldız çarklı & 44 & 170 & 7480 & 49.9 & 0.29 & 50.2 & 0.30 \\
\hline Tesviye küreği & Arka & - & 6 & 520 & 3120 & 20.8 & 0.04 & 20.9 & 0.04 \\
\hline Sapdöver Harman Mak. & Kuyruk mili & - & 28 & 1350 & 37800 & 252 & 0.19 & 253.7 & 0.19 \\
\hline \multirow{2}{*}{ Yem Karma Mak. } & Çekilir & $6 \mathrm{~m}^{3}$ & 12 & 2360 & 28320 & 188.8 & 0.08 & 190.07 & 0.08 \\
\hline & Çekilir & $8 \mathrm{~m}^{3}$ & 8 & 3400 & 27200 & 181.3 & 0.05 & 182.55 & 0.05 \\
\hline Toplam & & - & 928 & - & 610870 & 4072.5 & 6.25 & 4099.6 & 6.23 \\
\hline
\end{tabular}


Çizelge 7. Elektrik motorundan hareketli makinaların dağılımı.

Table 7. Distribution of the machines powered by electric motor.

\begin{tabular}{|c|c|c|c|c|c|c|c|c|}
\hline \multirow{3}{*}{$\begin{array}{l}\text { Tip } \\
\ddot{O} z e l l i k \\
\text { Güç, } k W\end{array}$} & \multicolumn{2}{|c|}{ Süt Sağım Makinası } & \multirow{3}{*}{$\begin{array}{c}\text { Yem Kırma Makinası } \\
150 \mathrm{~kg} \\
14.9\end{array}$} & \multirow{3}{*}{$\begin{array}{c}\text { Su pompası } \\
\text { Santrifüj } \\
1.5\end{array}$} & \multicolumn{2}{|c|}{ Helezon } & \multirow{2}{*}{\multicolumn{2}{|c|}{ Toplam }} \\
\hline & 1 ünite & 2 ünite & & & $8 m$ & $12 m$ & & \\
\hline & 0.75 & 0.75 & & & 4.1 & 5.6 & adet & $\mathrm{kW}$ \\
\hline Çerkeş & 14 & 3 & 4 & 2 & 2 & 6 & 31 & 117.2 \\
\hline Kurşunlu & 12 & 3 & 8 & 2 & 3 & 1 & 29 & 151.4 \\
\hline Ilgaz & 6 & 4 & 3 & 2 & 2 & 1 & 18 & 69.0 \\
\hline Şabanözü & 1 & 4 & 3 & 2 & 1 & - & 11 & 55.6 \\
\hline Eldivan & 8 & 6 & 5 & 2 & - & 3 & 24 & 104.8 \\
\hline Kizılırmak & 1 & 4 & 1 & - & 2 & 1 & 9 & 32.5 \\
\hline Yapraklı & 6 & - & - & - & 2 & 3 & 11 & 29.5 \\
\hline Merkez & 3 & 4 & 2 & - & 1 & 8 & 18 & 84.0 \\
\hline Toplam, adet & 51 & 28 & 26 & 10 & 13 & 23 & 151 & 643.8 \\
\hline$\%$ & 33.8 & 18.5 & 17.2 & 6.6 & 8.6 & 15.2 & 100 & - \\
\hline Toplam Güç, $k W$ & 38.3 & 21 & 387.4 & 15 & 53.3 & 128.8 & - & 643.8 \\
\hline$\%$ & 5.9 & 3.3 & 60.2 & 2.3 & 8.3 & 20.0 & 100 & - \\
\hline
\end{tabular}

Çizelge 8. Mekanizasyon düzeyi göstergeleri.

Table 8. Indicators of the mechanization level.

\begin{tabular}{|c|c|c|c|c|c|}
\hline İlçeler & kW ha-1 & kW işletme ${ }^{-1}$ & ha traktör-1 & ton-makina traktör ${ }^{-1}$ & traktör işletme ${ }^{-1}$ \\
\hline Çerkeş & 1.88 & 66.83 & 30.63 & 5.51 & 1.16 \\
\hline Kurşunlu & 1.81 & 66.74 & 29.85 & 4.66 & 1.24 \\
\hline Ilgaz & 2.30 & 55.97 & 20.84 & 3.58 & 1.17 \\
\hline Şabanözü & 3.06 & 40.90 & 14.25 & 3.32 & 0.94 \\
\hline Eldivan & 4.26 & 48.68 & 10.70 & 4.50 & 1.07 \\
\hline Kızılırmak & 1.79 & 43.59 & 28.61 & 3.32 & 0.85 \\
\hline Yapraklı & 2.25 & 30.72 & 21.25 & 2.78 & 0.64 \\
\hline Merkez & 2.27 & 53.69 & 23.65 & 4.85 & 1.00 \\
\hline Genel & 2.15 & 50.89 & 23.78 & 4.06 & 1.01 \\
\hline
\end{tabular}

gücü değeri, bu çalışmada belirlenen $2.15 \mathrm{~kW} \mathrm{ha}^{-1}$ değerinden \%43 daha fazladır. Daha yoğun yapılan tarımsal faaliyetlerin yapıldığı Batı Marmara bölgesindeki mekanizasyon düzeyinin, kuru tarıma dayalı üretimin yapıldı ̆̆ Çankırı ilinden daha yüksek çıkmasının beklenen bir sonuç olduğu söylenebilir.

Comart (2016) tarafindan Antalya ilinde yürütülen çalışmada elde edilen sonuçlar ile Çankırı ili sonuçları kıyaslandığında farklı kollarda üretim yapılan Antalya ilindeki mekanizasyon düzeyinin daha yüksek olduğu görülmektedir. Antalya ilinde birim alan başına düşen traktör gücü değeri $5.67 \mathrm{~kW} \mathrm{ha}^{-1}$ olarak hesaplanmıştır.

Yine sulu koşullarda tarla tarımının daha yoğun olarak yapıldığ 1 ve işletmelerin \%66'sının bitkisel üretim ile birlikte hayvancılık yaptığı Konya ili Çumra ilçesindeki işletmelerde ortalama traktör gücü $58.70 \mathrm{kWolarak}$ belirlenmiştir. Mekanizasyon düzeyi göstergeleri ise sirasıyla $4.08 \mathrm{~kW} \mathrm{ha}^{-1}$, 1.04 traktör işletme ${ }^{-1}, 60.89 \mathrm{~kW}$ işletme ${ }^{-1}, 14.39$ ha traktör $^{-1}$ ve 10.77 ton-makina traktör ${ }^{-1}$ olarak hesaplanmıştır (Keleş 2015). Çumra ilçesinde sulu koşullarda tarla tarımında gerçekleşen faaliyetler ile birlikte hayvan yetiştiriciliğine yönelik işlemlerin mekanizasyon düzeyini yükselttiği söylenebilir.

Bununla birlikte kuru tarla tarımının yoğun olarak yapıldığ 1 Adıyaman ili için belirlenen $0.22 \mathrm{~kW} \mathrm{ha}^{-1}$ değeri benzer şekilde tarımın yapıldığı Çankırı ili için belirlenen $2.15 \mathrm{~kW} \mathrm{ha}^{-1}$ değerinin çok altındadır. Çankırı ilinde bir traktör başına işlenen alan 23.78 ha traktör $^{-1}$ iken bu değer Adıyaman ili için 190.31 ha traktör ${ }^{-1}$ olarak belirtilmiştir (Lüle ve ark. 2012).

Şanlıurfa'nın Hilvan ilçesi için ortalama traktör gücü $45.44 \mathrm{~kW}$, birim alan başına düşen traktör gücü değeri $1.01 \mathrm{~kW} \mathrm{ha}^{-1}$, işletme başına düşen traktör sayıs1 0.92 adet işletme $^{-1}$, işletme başına düşen traktör gücü $41.65 \mathrm{~kW}$ şletme ${ }^{-1}$, traktör başına düşen makina sayıs1
5.65 adet traktör ${ }^{-1}$ olarak belirlenmiştir. Hilvan ilçesindeki işletmelerin \%35'inin bitkisel üretim ile hayvansal üretimi birlikte yürüttükleri belirtilmiştir (Ademoğlu 2015). Bu değerlere göre benzer şekilde bir üretim şekline sahip Çankırı ilinde mekanizasyon düzeyinin daha yüksek olduğu görülmektedir.

Ülke genelinde yapılan çalışmalar dikkate alındığında Çankırı ilindeki mekanizasyon uygulamalarının sulu koşullarda farklı üretim kollarında üretimin daha yoğun yapıldığı bölgelerden daha az, bununla birlikte kuru tarımda tahıl yetiştiriciliğinin yapıldığı benzer bölgelerden ise daha fazla olduğu belirlenmiştir. Benzer şekilde bitkisel üretimin ağırlıklı olduğu bölgelere göre daha fazla olmasının nedeninin Çankırı ilinde yapılan hayvansal üretim olduğu söylenebilir.

$\mathrm{Bu}$ çalışmada ayrıca elektrik motoru ile ilgili güç değerlerinin mekanizasyon düzeyine etkisi belirlenmiştir. Çizelge 9'da elektrik motor gücü kullanım düzeylerine ait bulgular verilmiştir.

Çizelge 9'a göre işletme başına yaklaşık bir adet elektrik motorundan hareketli tarım makinası düşmektedir. İşletme başına düşen ortalama elektrik motor gücü büyüklüğü $4.32 \mathrm{~kW}$ 'tır. Bu değerler Çizelge 8 'de yer alan ve aynı birimle belirtilen $\mathrm{kW}$ işletme ${ }^{-1}$ göstergesine eklendiğinde $50.89 \mathrm{~kW}$ işletme ${ }^{-1}$ olan gösterge, \%8.5'luk bir artışla $55.21 \mathrm{~kW}$ işletme ${ }^{-1}$ değerine çıkmaktadır. Hayvancılığın gelişmesi ile birlikte işletmelerdeki mekanizasyon düzeyinin de yükselmesi beklenmektedir.

Araştırma bulguları dikkate alındığında bölgede yapılacak planlama çalışmalarında bitkisel üretim ile birlikte hayvansal üretim potansiyeli ve faaliyetlerinin dikkate alınmasının kaçınılmaz olduğu söylenebilir. 
Çizelge 9. İşletmelerde elektrik motor gücü kullanım düzeyi. Table 9. Usage Levels of electric motor power in the farms.

\begin{tabular}{|c|c|c|c|c|c|}
\hline \multirow{2}{*}{ İlçeler } & \multirow{2}{*}{ İşletme Sayısı (adet) } & \multicolumn{4}{|c|}{ Elektrik Motorundan Hareketli Makina } \\
\hline & & Sayı (adet) & Toplam Güç (kW) & adet ișletme $^{-1}$ & kW işletme ${ }^{-1}$ \\
\hline Çerkeş & 19 & 31 & 117.2 & 1.63 & 6.17 \\
\hline Kurşunlu & 21 & 29 & 151.4 & 1.38 & 7.21 \\
\hline Ilgaz & 12 & 18 & 69.0 & 1.50 & 5.75 \\
\hline Şabanözü & 16 & 11 & 55.6 & 0.69 & 3.48 \\
\hline Eldivan & 15 & 24 & 104.8 & 1.60 & 6.99 \\
\hline Kızılırmak & 27 & 9 & 32.5 & 0.33 & 1.20 \\
\hline Yapraklı & 14 & 11 & 29.5 & 0.79 & 2.11 \\
\hline Merkez & 25 & 18 & 84.0 & 0.72 & 3.36 \\
\hline Toplam & 149 & 151 & 643.8 & 1.01 & 4.32 \\
\hline
\end{tabular}

\section{Sonuçlar}

$\mathrm{Bu}$ araştırmada elde edilen sonuçlar ve öneriler aşağıdaki şekilde özetlenebilir.

Sahiplerinin yaklaşık \%75 gibi bir çoğunlukla ilköğretim mezunu olduğu tarımsal işletmelerde, deneyim süresi yaklaşık 29 yıldır. Tarımsal faaliyetlerin orta yaş düzeyi ve üzeri ilköğretim mezunu kişiler tarafindan yürütüldüğü görülmektedir.

İşletmelerde ortalama arazi büyüklüğü 22.9 ha olarak belirlenmiştir. $\mathrm{Bu}$ değer ile Çankırı ilinde ülkemiz ortalama işletme büyüklüklerinin üzerindeki alanlarda tarımsal üretimin yapıldığı görülmektedir. Mülk ile birlikte kiralık parsellerde üretimin ağırlıklı olduğu bölgede işletmelerdeki parsel sayısı fazladır ve ortalama parsel büyüklüğü 0.81 ha'dır. Tarımsal üretimde verimliliği azaltma ve maliyetleri artırma potansiyeli içeren bu özellik nedeni ile bölgede arazi toplulaştırmasına yönelik çalışmalara ağırlık verilmesinin yararlı olacağı söylenebilir.

İlde kuru koşullarda tarla tarımı hakimdir. İşletmelerin yaklaşık \%70'in de bitkisel üretim ile birlikte hayvan yetiştiriciliği beraber yürütülmektedir. Büyükbaş havyan yetiştiriciliği daha yaygındır.

İşletme başına yaklaşı bir adet traktör düşmektedir. Traktörlerin model ve tip dağılımında çeşitlilik bulunmaktadır. İşletmelerdeki traktörlerin yaklaşık yarısının beş yaşın altında olması, traktörlerin yenilenme eğiliminde olduğunu göstermektedir. Traktör park1 ile ilgili önemli göstergelerden birisi olan ekonomik ömür içerisindeki traktörlerin oranı yaklaşık \%70'dir. Tarımsal işlemlerin çoğunlukla yeni ve ekonomik ömür içerisindeki traktörler tarafindan geçekleştirilmesinin, mekanizasyon uygulamalarının verimliliği açısından olumlu olduğu söylenebilir.

İşletmelerdeki makinalar, traktörden ve elektrik motorundan hareketli makinalar olmak üzere iki grupta değerlendirilmiştir. Traktör başına ortalama 6.25 adet ve 4.07 ton tarım makinası düşmektedir. Yaklaşık 0.9 adet işletme ${ }^{-1}$ değerleri ile işletmelerde en fazla tarım arabası, kulaklı pulluk ve kültüvatör bulunmaktadır. Makinalar ağırlıklı olarak tarla tarımında kullanılan makinalardır. Bununla birlikte hayvan yetiştiriciliğinde kullanılan makinalar da dikkat çekmektedir.

Mekanizasyon düzeyi göstergeleri dikkate alındığında Çankırı ili için; birim alan başına düşen ortalama traktör motor gücü $2.15 \mathrm{~kW} \mathrm{ha}^{-1}$, işletme başına düşen motor gücü
$50.89 \mathrm{~kW}$ işletme $^{-1}$ ve traktör başına düşen tarım alanı 23.78 ha traktör $^{-1}$ olarak hesaplanmıştır. İlçelere ait mekanizasyon düzeyi göstergelerine tarım alanlarının genişliği ile birlikte tarımı yapılan ürün çeşitliliğinin de etkili olduğu görülmektedir.

İşletme başına yaklaşık bir adet elektrik motorundan hareketli makina düşmektedir. İşletme başına düşen ortalama elektrik motor gücü büyüklüğü ise $4.32 \mathrm{~kW}$ 'tır. $\mathrm{Bu}$ değerler traktör gücüne eklendiğinde $50.89 \mathrm{~kW}$ işletme ${ }^{-1}$ olan gösterge $\% 8.5$ 'luk bir artışla $55.21 \mathrm{~kW}$ işletme ${ }^{-1}$ değerine çıkmaktadır. Hayvancılığın gelişmesiyle birlikte işletmelerdeki mekanizasyon düzeylerinin de yükselmesi beklenmektedir. Elektrik motorundan hareketli makinalar çoğunlukla hayvan yetiştiriciliğinde kullanılmaktadır. Teknoloji kullanımının yaygınlaşması, işgücü teminindeki zorluk ve maliyetlerin yükselmesi gibi faktörler sabit tesislerde elektrik motorundan hareketli makinaların kullanımı artırmaktadır. $\mathrm{Bu}$ nedenle yapılacak benzer çalışmalarda bu tip makinaların da çalışma kapsamında değerlendirilmesi önerilir.

Araştırma sonuçlarına göre il genelinde yapılacak planlama vb. çalışmalarda, hayvansal üretim potansiyeli ve faaliyetlerinin de dikkate alınması gereklidir.

Bölgeye yönelik optimum traktör gücü ve tarım makinası büyüklüklerinin belirlenmesine yönelik çalışmaların yapılmasının yararlı olacağı öngörülmektedir. Bu kapsamda, çalışmada elde edilen veri tabanı ile belirlenecek optimum değerlerin kıyaslanması sonucu bölge mekanizasyonun güç ve kapasite eksikleri veya fazlalıklarının değerlendirilme imkanı doğacaktır.

\section{Teșekkür}

Bu çalışma Akdeniz Üniversitesi Bilimsel Araştırma Projesi tarafindan FYL-2018-3912 nolu yüksek lisans tez projesi ile desteklenmiştir.

\section{Kaynaklar}

Ademoğlu MA (2015) Şanlıurfa ili hilvan ilçesinde tarım işletmelerinin tarımsal mekanizasyon düzeyinin belirlenmesi. Yüksek Lisans Tezi, Harran Üniversitesi Fen Bilimleri Enstitüsü, Şanlıurfa.

Akıncı İ, Topakcı M, Çanakcı M (1997) Antalya bölgesi tarım işletmelerinin tarımsal yapı ve mekanizasyon özellikleri. Tarımsal Mekanizasyon 17. Ulusal Kongresi Cilt 1, Tokat, s. 45-58.

Altıkat S, Çelik A (2011) Iğdır ilinin tarımsal mekanizasyon özellikleri. Iğdır Üni. Fen Bilimleri Enst. Der. / Iğdır Univ. J. Inst. Sci. \& Tech. 1(4): 99-106. 
Altuntaş E, Demirtola H (2004) Ülkemizin tarımsal mekanizasyon düzeyinin coğrafik bölgeler bazında değerlendirilmesi, GOÜ. Ziraat Fakültesi Dergisi 21(2): 63-70.

Anonim (2017) Çankırı Tarım ve Orman Müdürlüğü Kayıtları, Çankırı.

Baran MF, Gökdoğan O, Durgut MR (2014) Batı Marmara Bölgesi'nin tarımsal mekanizasyon özellikleri, Türk Tarım ve Doğa Bilimleri Dergisi 1(4): 561-567.

Cengil B (2013) Sıcaklık ve Güneşlenme Sürelerinin Çankırı Ekolojik Kaynakları Açısından Değerlendirilmesi. Biyoloji Bilimleri Araştırma Dergisi 6(2): 23-27.

Comart A (2016) Antalya ili tarım işletmelerinin tarımsal yapı, üretim ve mekanizasyon özelliklerinin belirlenmesi. Yüksek Lisans Tezi. Akdeniz Üniversitesi Fen Bilimleri Enstitüsü, Antalya.

Çanakcı M (2005) Antalya ili sera sebzeciliğinde mekanizasyon işletmeciliği verilerinin belirlenmesi ve optimum seçim modellerinin oluşturulması üzerine bir araştırma. Doktora Tezi, Akdeniz Üniversitesi Fen Bilimleri Enstitüsü, Antalya.

Çiçek G, Özpınar S (2007) Gönen ilçesindeki (Balıkesir) çeltik işletmelerinin tarımsal yapısı ve mekanizasyon durumu. Tarımsal Mekanizasyon 24. Ulusal Kongresi Bildiriler Kitabı, Kahramanmaraş, s. 74-81.

ÇKS (2017) Tarım ve Orman Bakanlığı Çiftçi Kayıt Sistemi Veritabanı, Ankara.

Evcim Ü, Ulusoy E, Gülsoylu E, Tekin AB (2010) Tarımsal mekanizasyonun durumu, sorunları ve çözüm önerileri. Ziraat Mühendisliği VII. Teknik Kongresi, Ankara.

Gökdoğan O (2013) Hakkari ilinin tarımsal mekanizasyon durumu. Türk Tarım ve Doğa Bilimleri Dergisi 1(1): 98-101.
Keleş İ (2015) Cumra ilçesi tarım işletmelerinin tarımsal yapısı ve mekanizasyon özelliklerinin belirlenmesi. Yüksek Lisans Tezi, Selçuk Üniversitesi Fen Bilimleri Enstitüsü, Konya.

Lüle F, Koyuncu T, Engin KE (2012) Adıyaman ilinin tarımsal mekanizasyon düzeyi. 27. Tarımsal Mekanizasyon Ulusal Kongresi, Samsun, s. 48-54.

Magalhães AC, Souza JM, Santana MA, Sabbg OJ (2013) Analysis of the mechanization index of wheel tractors in rural farm holdings. Journal of Agricultural Science 5(11): 127-138.

MGM (2016) Meteoroloji Genel Müdürlüğü. http://www.mgm.gov.tr. Erişim 10 Aralık 2016.

Özkan B (1993) Aksu sulama projesi alanına giren tarım işletmelerinin ekonomik analizi ve ürün desenini etkileyen faktörler. Doktora Tezi, Çukurova Üniversitesi Fen Bilimleri Enstitüsü, Adana.

Sağlam C, Akdemir B (2002) Annual ussage of tractors in North-West Turkey. Biosystems Engineering 82(1): 39-44.

Singh D, De D (1999) Quantification of a mechanization indicator for Indian Agriculture, Applied Engineering in Agriculture 15(3): 197-204.

Yılmaz S, Sümer SK (2018) Türkiye'de traktör parkı yenilenme oranları ve mekanizasyon düzeyinin belirlenmesi. Tarım Makinaları Bilimi Dergisi (Journal of Agricultural Machinery Science) 14(2): 79-87.

Zeren Y, Tezer E, Tuncer İK, Evcim Ü, Güzel E, Sındır KO (1995). Tarım alet makina ve ekipman kullanım ve üretim sorunları. Ziraat Mühendisliği Teknik Kongresi, Tarım Haftası, Ankara, s. 9-13. 